\title{
ミクロのブロックを積む
}

\author{
谷 俊 彦 \\ 株式会社豊田中央研究所 齿480-1192 愛知県長久手町
}

(2001 年 3 月 7 日受理)

\section{Building a Brick Wall of Perovskite-type Polycrystals}

\author{
Toshihiko TANI
}

Toyota Central R\&D Labs., Inc.

Nagakute, Aichi 480-1192

(Received March 7, 2001)

\begin{abstract}
We developed a novel processing method, the reactive templated grain growth (RTGG), for the fabrication of highly textured polycrystalline ceramics with a regular perovskite-type structure. Plate-like particles with a layered perovskitetype structure were used as a reactive template, of which the preferred orientation was preserved in the in-situ formed regular perovskite-type polycrystals after heat-treatment. The textured ceramics exhibited a brick-wall-like microstructure and enhanced piezoelectric properties. The mechanism of conversion from a layered perovskite-type template into a regular perovskite-type product was rather topotactic. Furthermore, the RTGG processing was also applied to the fabrication of more complex bismuth layer-structured (BLS) ceramics with a preferred $\{001\}$ orientation. The textured BLS ceramics exhibited 3-4 times as high piezoelectric coefficients and electromechanical coupling factors as the conventionally sintered BLS ceramics of the same compositions. The textured BLS ceramics showed a layered-slate-like microstructure. The unique microstructures of the two types of textured ceramics ( $\{100\}$-oriented regular perovskite and $\{001\}$-oriented BLS) reflected anisotropy in terms of the surface energy for the crystal structures of regular perovskite and BLS.
\end{abstract}

\section{1.は じめに}

筆者が教養部の学生時代に読んだ，イラストレーショ ンを多用して金属の物理や化学を易しく説いた本の中 に 教室に男女生徒の机が隣どうしに規則正しく並んだ， 「結晶」についての解説があった スの男女は授業中教室で並んでいるかもしれないが, 運 動場で学校中の騒がしい生徒全体を規則正しく整列させ ようとする先生の苦労は並大抵のものではない。クラス ごとには担任の方を向いていても，学校全体 (バルク) としてはてんでばらばらの方向を見ている。

光れでも，焦電体や圧電体のように極性を持つ物質を， 「素子」と言えるほどのサイズで方位を光ろえると，人 間が利用できる特性を発揮するため, これまで多くの先 生たちが知恵を絞ってきた。一番簡単な方法は, 校庭で

E-mail: toshit@mosk.tytlabs.co.jp
めいめい勝手に遊んでいる子供たち（無配向多結晶セラ ミックス) に一方向から大声で命令を下してスピーカー の方に顔だけを向かせる，というやり方 (分極処理) で ある。これは生産性の点からは最も有利なやり方である が, 単結晶の持つ固有の物性を多結晶体の材料特性とし てフルに引き出すことは望めない。光こで，もつと整然 と並ばせようと知恵を絞ることになる。

最も一般的に行われるのは, まずは従順な男女生徒だ けを交互に一列並べておき，彼らに続いて同じ法則で並 ぶように，と他の子供たちに命ずることである（エピタ キシー)。この場合, 列の数が限られている場合には生 徒は比較的言うことを聞く。筆者もかつて，「単結晶基 板」と称する模範生徒を利用するこのやり方で, 強誘電 体の擬単結晶薄膜を作製していたことがある21。実際， 薄膜の場合には体積に対して界面の面積が大きいため， 模範生徒を使わずとも表面エネルギーや界面エネルギー にいくばくかの異方性があれば生徒は特定の方向に並ぶ 
傾向を見せる (self texture)。Fig. 1 に self texture を利用 してゾルゲル法で作製した厚さ $0.3 \mu \mathrm{m}$ の反強誘電性 $\mathrm{PbZrO}_{3}$ 薄膜の $\mathrm{X}$ 線回折パターンを示す。ここでは, ア モルファス $\mathrm{SiO}_{2}$ 上の $\mathrm{Pt}$ 電極の表面処理法を変えること

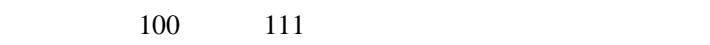
晶表示) した薄膜を作り分けている3)。前者は他の結晶 面より表面エネルギーが低いペロブスカイト型結晶の self texture であり，後者は Pt の self texture による $\{111\}$ 面上エピタキシャル配向である。 $\mathrm{PbZrO}_{3}$ は特定の方位 に分極軸を持つため, 2 種類の薄膜はまったく異なる分 極量-電界ヒステリシス特性を示す (Fig. 2)。

しかし , バルク材料が必要な応用の場合にはさらに苦 労が多い。基本的に模範生徒を使うのと同じ方法で, 長 時間かけて校庭の端から辛抱強く並ばせるのがチョクラ ルスキー法による単結晶成長である。これはたいへん時 間のかかる作業である。途中で不良グループが固まって 核生成すると, 方位の異なる結晶粒が生じてしまう。な んとか楽して並ばせる方法はないものだろうか?

$\mathrm{Bi}_{4} \mathrm{Ti}_{3} \mathrm{O}_{12}$ のような層状ペロブスカイト型結晶（Fig. 3) は表面 (界面) エネルギーの異方性が大きいので, Fig. 4 のように c 面が発達した板状粒子の合成が容易にでき る(写真はフラックス法で合成した)。この単結晶粉末 をテープ成形のように剪断応力が作用する手法で一面に 並べ, 焼結することによって $\{001\}$ 面か配向した多結 晶を作製することが可能である ${ }^{4}$ 。高温で剪断応力を加

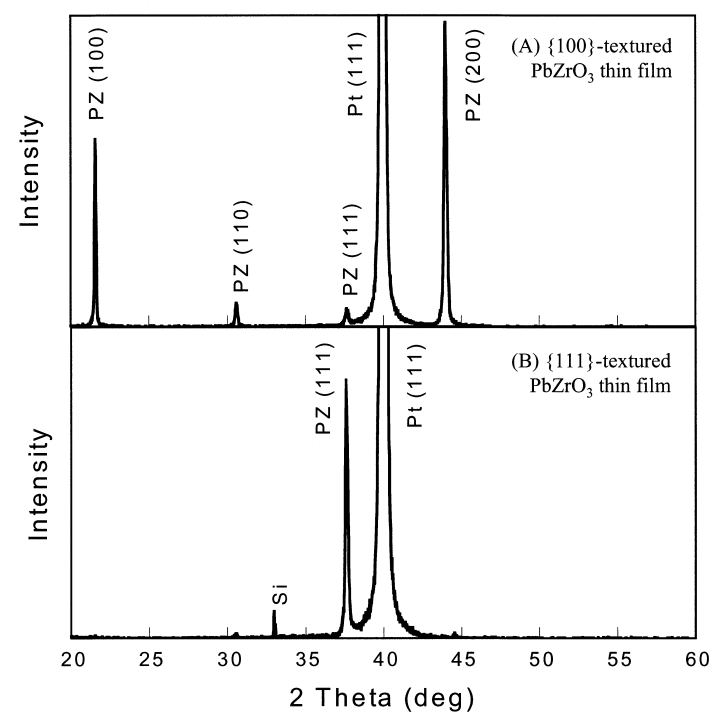

Fig. 1 X-ray diffraction patterns of sol-gel derived $\mathrm{PbZrO}_{3}$ thin films with (A) a preferred $\{100\}$ orientation and (B) a preferred $\{111\}$ orientation, on surfacemodified $\mathrm{Pt} / \mathrm{Ti} / \mathrm{SiO}_{2} / \mathrm{Si}$ substrates.
えて配向化することもできる5”。しかし，残念ながら， 工学的に重要な圧電体焦電体の多くはFig. 5 のような (単純) ペロブスカイト型構造である。この構造はほぼ 等方的であり, 特有の滑り面も持たない。融液中・溶液 中での単結晶成長では $\{100\}$ ファセットが発達しやす いが,表面エネルギーの異方性は小さく,バルクでの self texture 利用は困難である。かつて配向フェライト磁気へ ッドで成功したようなスピネル構造 (フェライト) に対 するコランダム構造 $\left(\alpha-\mathrm{Fe}_{2} \mathrm{O}_{3}\right)$ のようなトポタキシー 合成が可能なシード物質もない( $)$ 。うーむ $\cdots \cdots$, 待てよ， Fig. 3 と 5 とは狭い意味でのトポタクティックな関係 (3

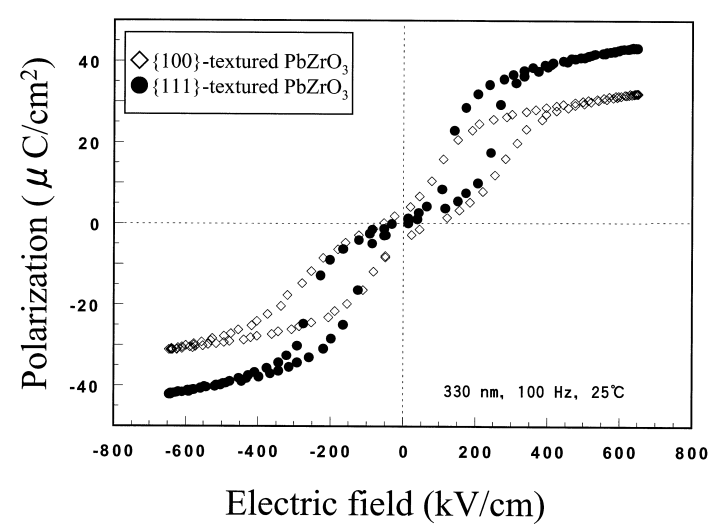

Fig. 2 Polarization-electric field hysteresis loops for $\mathrm{PbZrO}_{3}$ thin films with preferred $\{100\}$ and $\{111\}$ orientations.

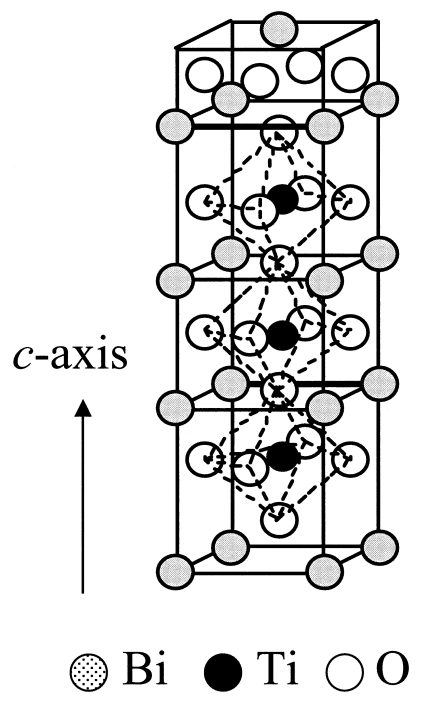

Fig. 3 A quarter unit cell of bismuth layer-structured $\mathrm{Bi}_{4} \mathrm{Ti}_{3} \mathrm{O}_{12}$ (BIT) crystal structure. 
次元格子整合) にはないが，2 次元的な格子整合性があ るではないか。光れならば, エピタキシーが使えるので はないか? バルク中に無数の層状ペロブスカイト型基 板結晶を敷き詰めておき，これをテンプレートとして擬 等方ペロブスカイト型結晶をエピタキシャル生成させ， さらに基板まで反応させて消してしまう一-Reactive Templated Grain Growth（RTGG）法によるペロブスカイ

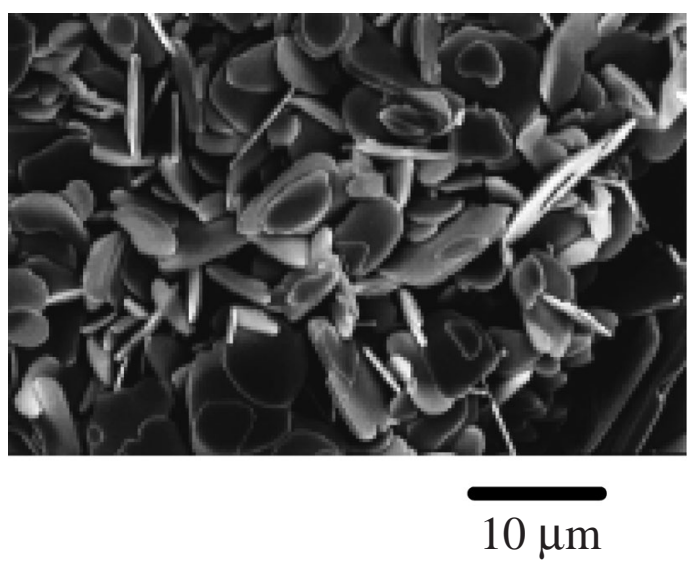

Fig. 4 SEM image of plate-like $\mathrm{Bi}_{4} \mathrm{Ti}_{3} \mathrm{O}_{12}$ (BIT) particles prepared by a molten salt synthesis.

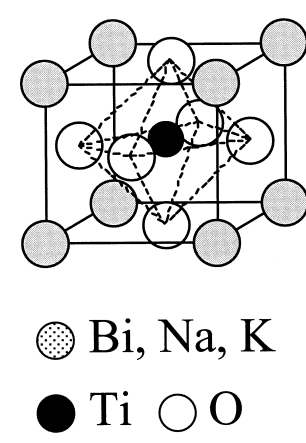

Fig. 5 A unit cell of regular perovskite-type $\mathrm{Bi}_{0.5}(\mathrm{Na}, \mathrm{K})_{0.5}$ $\mathrm{TiO}_{3}(\mathrm{BNKT})$ crystal structure.
卜型配向多結晶の作製技術は光んな発想から生まれ た7)。

2. Reactive Templated Grain Growth 法による 配向制御

鉛を含まないペロブスカイト型圧電材料である $\mathrm{Bi}_{0.5}(\mathrm{Na}, \mathrm{K})_{0.5} \mathrm{TiO}_{3}$ (BNKT) が , Fig. 4 の $\mathrm{Bi}_{4} \mathrm{Ti}_{3} \mathrm{O}_{12}$ (BIT) 板状粉末をテンプレートとして他の粉末原料 $\left(\mathrm{Bi}_{2} \mathrm{O}_{3}\right.$, $\left.\mathrm{TiO}_{2}, \mathrm{Na}_{2} \mathrm{CO}_{3}, \mathrm{~K}_{2} \mathrm{CO}_{3}\right)$ との反応後に合成される組成と， テンプレートが残る組成とを用意した。テンプレートの 配合量は弚れ光れ Ti 原子換算で 20 \% である。プロセス の模式図を Fig. 6 に示す。

まず, テンプレートが残らない組成, 即ち使用した全 原料の元素比が, $\mathrm{Bi}:(\mathrm{Na}+\mathrm{K}): \mathrm{Ti}=1: 1: 2$ テンプレー 卜か関与する反応設計は (単純化するために K を含ま ない $\mathrm{Bi}_{0.5} \mathrm{Na}_{0.5} \mathrm{TiO}_{3}(\mathrm{BNT})$ で考える)，

$(1 / 8) \mathrm{Bi}_{4} \mathrm{Ti}_{3} \mathrm{O}_{12}+(1 / 4) \mathrm{Na}_{2} \mathrm{CO}_{3}+(5 / 8) \mathrm{TiO}_{2}$

$$
\rightarrow \mathrm{Bi}_{0.5} \mathrm{Na}_{0.5} \mathrm{TiO}_{3}+(1 / 4) \mathrm{CO}_{2} \uparrow
$$

である。一方, テンプレートの間のマトリックス部分で は, 以下の反応で無配向 BNT 微粒子が生成する。

$$
\begin{aligned}
(1 / 4) \mathrm{Na}_{2} \mathrm{CO}_{3}+(1 / 4) \mathrm{Bi}_{2} \mathrm{O}_{3}+\mathrm{TiO}_{2} \\
\rightarrow \mathrm{Bi}_{0.5} \mathrm{Na}_{0.5} \mathrm{TiO}_{3}+(1 / 4) \mathrm{CO}_{2} \uparrow
\end{aligned}
$$

これらの in-situ 反応は成形体を膨張させ, 緻密化前 の試料密度を低下させるため, マトリックスの原料の代 わりに，あらかじめ固相合成した BNTや BNKT 微粉末 を“フィラー”として入れておいても良い。

以上のように反応設計した原料粉末を湿式混合し, ド クターブレード法でテープ成形すると， BIT テンプレー 卜粉末は剪断応力によって一方向に並ぶ。このテープを 積層圧着して厚さ数 $\mathrm{mm}$ のバルク成形テープとし, 熱 処理を行うと, 擬立方 $\{100\}$ 面か配向した一軸配向多 結晶セラミックスが作製される。テーブ試料表面の結晶 相の変化と配向組織の発達を高温 X 線回折 (Fig. 7) と

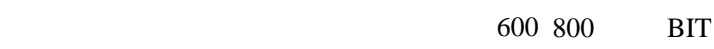
テンプレートの配向を維持したペロブスカイト型 BNKT 核が生成する7)。続いて $1000^{\circ} \mathrm{C}$ を超える温度で配向核

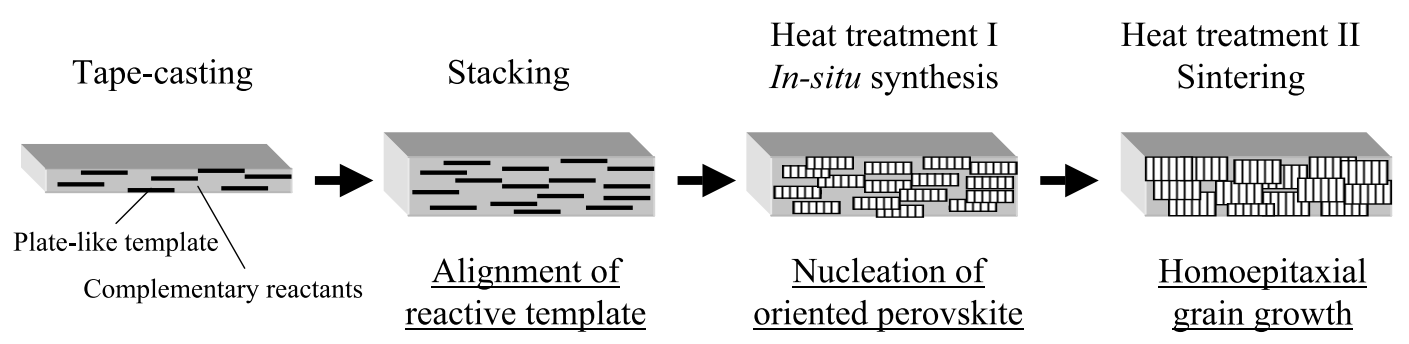

Fig. 6 A schematic diagram of RTGG processing method with texture development. 


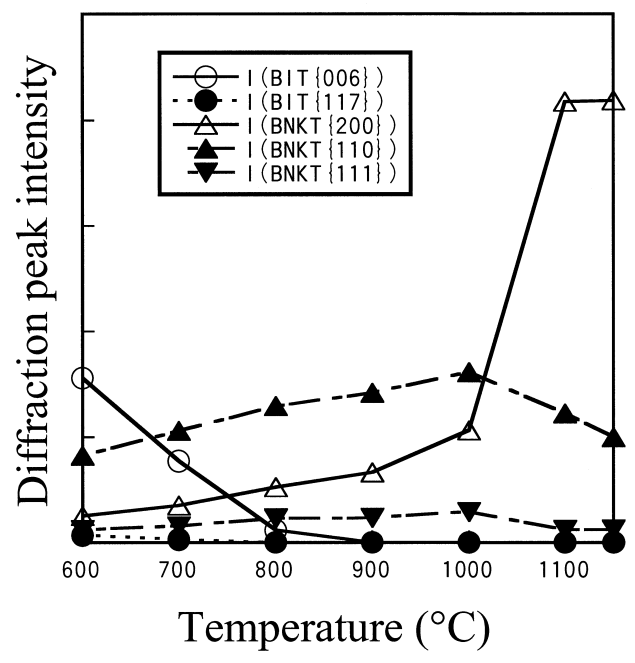

Fig. 7 Results of high-temperature X-ray diffraction analysis for RTGG-processed BNKT ceramics during conversion reaction on BIT template.
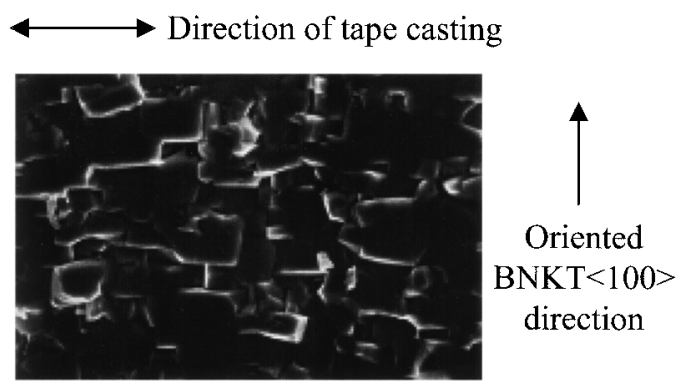

(A)
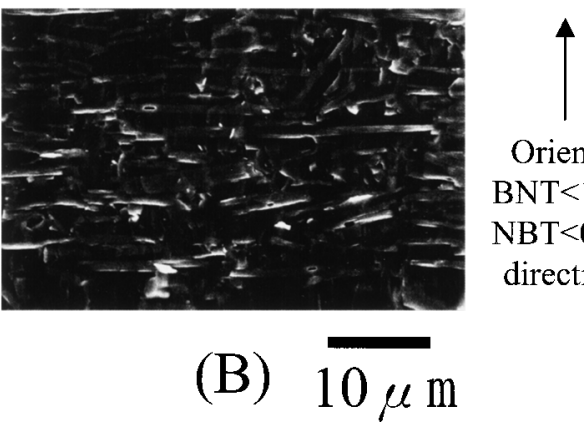

Oriented

$\mathrm{BNT}<100>$

$\mathrm{NBT}<001>$

directions

Fig. 8 SEM images of unique microstructures for (A) textured BNKT ceramics and (B) textured BNT-NBT composites.

が無配向微結晶を取り込みながら粒成長してテンプレー 卜間を埋め，バルク全体を緻密な一軸配向多結晶に転換 する。Fig. 8 (A) にはこの方法を用い, テンプレート

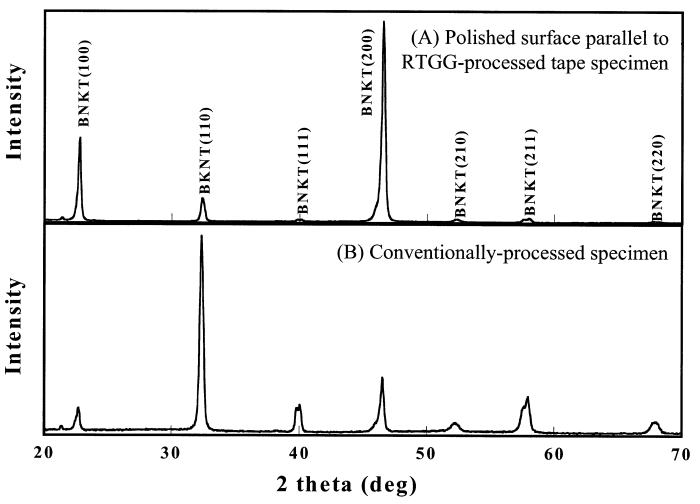

Fig. 9 X-ray diffraction patterns of (A) RTGG-processed (highly-textured) and (B) conventionally-processed (randomly-oriented) BNKT ceramics.

が残らない組成で作製した BNKT 焼結体のテープ面に 垂直な破断面 SEM 像を示す ${ }^{8)}$ 。ペロブスカイト型構造 で表面エネルギーが相対的に小さな擬立方 $\{100\}$ 面を ファセットとして粒成長が進行するため，まるて煉瓦塀 あるいはブロック塀のような特異な組織となる。

テープに平行な面のX 線回折パターンを Fig. 9 (A) に示す。従来法で作製した無配向 BNKT セラミックス (Fig. 9 (B)) に比べ, 擬立方 $\{100\}$ の回折強度が著し く高い。配向度の簡便な評価法として, X線回折ピーク 強度の相対比較值を出す Lotgering 法が知られている。 配向度 F は単結晶ならば 1 ，従来法で作製した無配向多 結晶は 0 であるが，RTGG 法で作製した BNKT セラミ ックスは $\mathrm{F}=0.8$ 以上に達する。

このようにして作製した BNKT セラミックスの配向 面に平行な面に電極を設けて分極処理を施し，圧電特性 を測定した。Fig. 10，11に示すように，同組成の無配 向セラミックスと比べ, 30-40％ 高い電気機械結合係数 $\left(\mathrm{K}_{\mathrm{p}}\right)$ および $50-60 \%$ 高い圧電定数 $\left(\mathrm{d}_{31}, \mathrm{~g}_{31}\right)$ を示した ${ }^{8}$ 。 また，比誘電率は同程度の值であったが, 誘電損失は 20$40 \%$ 程度低減される。これらの特性向上は，〈111〉方 向に分極軸を持つペロブスカイト型圧電単結晶を〈100 方向に分極すると圧電特性を利用方向に引き出すのに有 利な分域ばかりになる，いわゆる「エンジニアード・ド メイン」に近い構造が, 多結晶でも実現しているためと 考えられる9”。

熱処理の第一段階を透過電子顕微鏡によって調べる と, Fig. 12 に示すように $700^{\circ} \mathrm{C} \times 5 \mathrm{~min}$ という短時間で 層状ペロブスカイト構造 BIT の表面近傍の格子に乱れ が生じ， $700^{\circ} \mathrm{C} \times 30 \mathrm{~min}$ では既にテンプレート粒子の内 部は, ペロブスカイト構造の配向核を分域として成る 2 


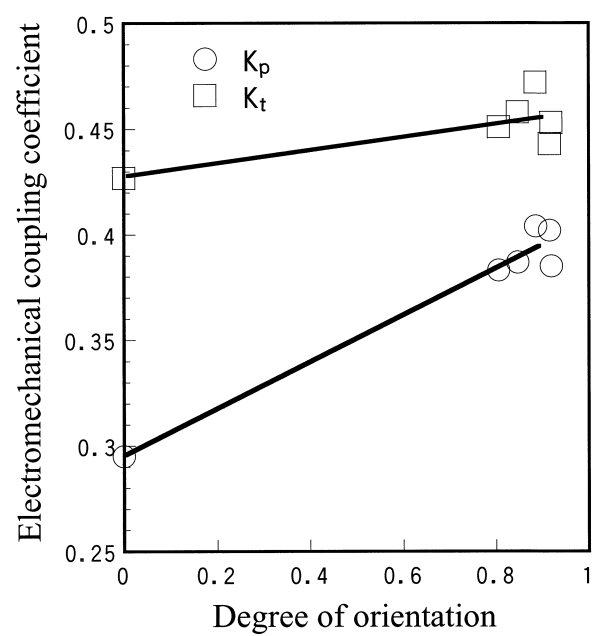

Fig. 10 Electromechanical coupling coefficients, $K_{p}$ (planar mode) and $\mathrm{K}_{\mathrm{t}}$ (thickness mode), for BNKT ceramics as a function of Lotgering's degree of orientation.

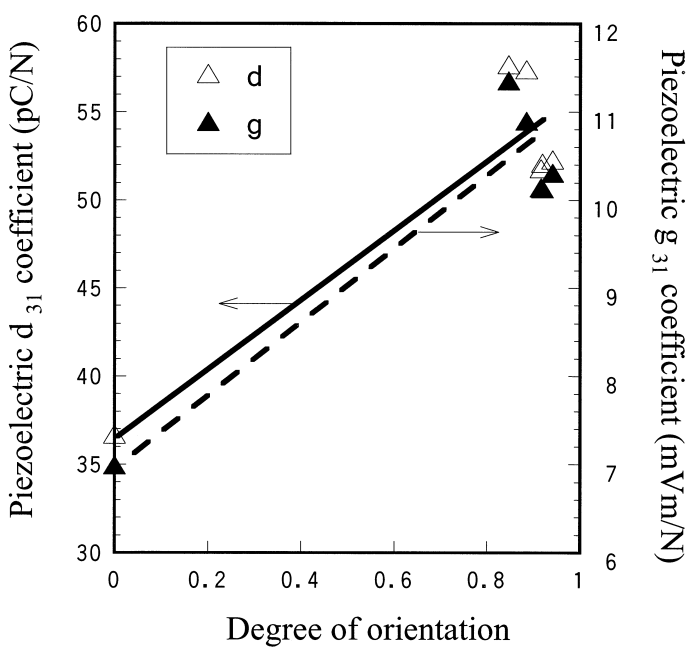

Fig. 11 Piezoelectric coefficients, $d_{31}$ and $g_{31}$, for BNKT ceramics as a function of Lotgering's degree of orientation.

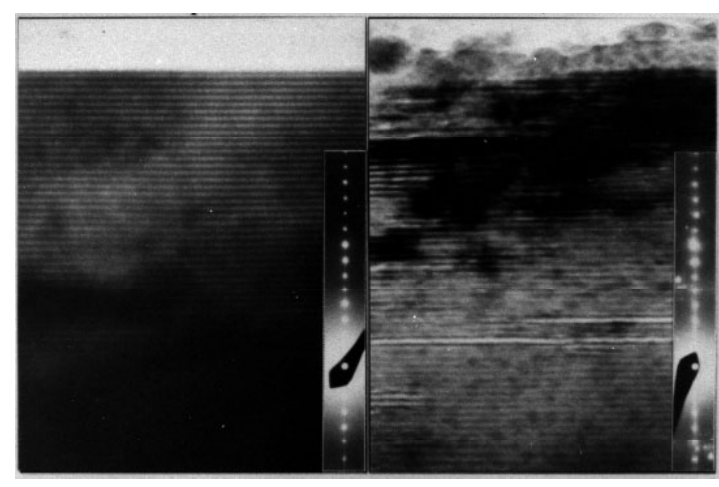

(A) Original template: Plate-like template particle, $\mathrm{Bi}_{4} \mathrm{Ti}_{3} \mathrm{O}_{12}$, is a layer-structured single crystal.
(B) $700^{\circ} \mathrm{C} \times 5 \mathrm{~min}:$ Reaction started within $\sim 50 \mathrm{~nm}$ inside the surface of the reactive template and its layer structure was disordered.

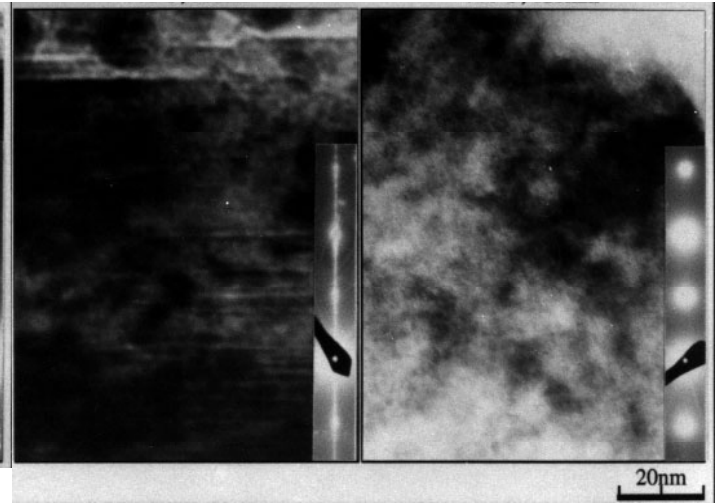

(C) $700^{\circ} \mathrm{C} \times 30 \mathrm{~min}:$

The reaction proceeded toward the inner part, in which the periodic structure turned to be confused and extinct.
(D) $700^{\circ} \mathrm{C} \times 120 \mathrm{~min}$ : The layer structure was no longer observed and the template was turned into regular perovskite, $\mathrm{Bi}_{0.5}(\mathrm{Na}, \mathrm{K})_{0.5} \mathrm{TiO}_{3}$.

Fig. 12 Bright field TEM images observed at the plane containing pseudo c-axis and electron diffraction patterns along the pseudo c-axis, for (A) a BIT template particle, and template particles in the RTGG-processed specimens after heattreatment at $700{ }^{\circ} \mathrm{C}$ for (B) $5 \mathrm{~min},(\mathrm{C}) 30 \mathrm{~min}$, and (D) $120 \mathrm{~min}$.

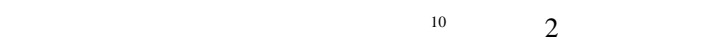
晶が再び単結晶化することにより, 試料内で板状のペロ ブスカイト型テンプレートとなる。反応後のテンプレー 卜は熱処理の第二段階 (焼結過程) でホモエピタキシャ ル粒成長し，バルク全体が一軸配向多結晶となる。BIT テンプレートの表面内でトポタキシーに類似の反応が進
行するのと平行して , 表面上ではへテロエピタキシー反 応も進行している。しかしながら，着手した時の予想と

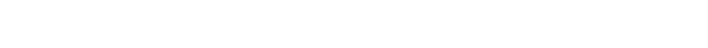
イト転換反応は前者が支配的であることがわかった。 この配向組織設計は，

(1) ペロブスカイト構造と層状ペロブスカイト構造の 
間に格子整合性があること，

(2) 組成に過不足が無ければ一般に層状ペロブスカイ 卜よりもペロブスカイトの方が熱力学的に安定であるこ と,

(3) 層状ペロブスカイト型構造の化合物は結合エネル ギーの異方性が強く, フラックス法などにより板状粉末 の合成が容易であること，

を利用したものである。

即ち，校庭の端から辛抱強く生徒たちを並べていかな くても,グラウンドにおおよ光平行になるよう長椅子(テ ンプレート）を配置しておけば，何人かの生徒たちが自 然にこれに腰をかけ，しかる後，弚の前に整然と集まり 始めるのである。この比喻からもわかるように, RTGG 法による配向セラミックス作製技術は自己組織化の一種 と考えられる。

\section{3 . 層状ペロブスカイト型化合物への展開}

前者の反応設計とは異なり，BIT テンプレートが BNT 生成反応に関与しなくて済む混合比, 即ち $\mathrm{Bi}_{4} \mathrm{Ti}_{3} \mathrm{O}_{12}$ : $\mathrm{Na}_{2} \mathrm{CO}_{3}: \mathrm{Bi}_{2} \mathrm{O}_{3}: \mathrm{TiO}_{2}=1 / 3: 1: 1: 4$ で原料を混合すると， テンプレートの粒子と粒子の間では，反応 (2) によっ てペロブスカイト型結晶が生じ， BIT と BNT との配向 コンポジットができると考えた。しかしながら，この両 者は $1100^{\circ} \mathrm{C}$ 以上でさらに反応，

$$
\begin{aligned}
\mathrm{Bi}_{4} \mathrm{Ti}_{3} \mathrm{O}_{12} & +\mathrm{Bi}_{0.5} \mathrm{Na}_{0.5} \mathrm{TiO}_{3} \\
& \rightarrow \mathrm{Na}_{0.5} \mathrm{Bi}_{4.5} \mathrm{Ti}_{4} \mathrm{O}_{15}(\mathrm{NBT})
\end{aligned}
$$

により BIT (3 層) とは別の層状ペロブスカイト型結晶 (4 層) に変わった。NBT はもちろんテンプレートの配 向を引き継いだトポタクティックな反応により $\mathrm{c}$ 面一軸 配向を維持するが，マトリックスにあたるBNT も固相 ヘテロエピタキシーにより配向化する。Fig. 13 のX線 回折パターンにより，\{001\}面か配向したNBT と，\{100\} 面が配向した BNT との複相組織になっていることが確 認できる ${ }^{8)}$ 。この結果, ペロブスカイト/層状ペロブス カイト複相配向多結晶である焼結体のテープ面に垂直な 破断面は, Fig. 8 (B) のように，あたかも NBT 製スレ 一トの間を BNKT の漆喰（しかも，スレートと格子整 合がある!) で埋めたような特異な微組織を呈した。

即ち, 前章の条件 (2) と同樣に，4層層状ペロブス カイト型構造 (NBT) は 3 層層状ペロブスカイト型構造 (BIT) よりも熱力学的に安定であることがわかる。こ れをさらに利用して , 複雑組成の層状ペロブスカイト構 造化合物の配向多結晶を BIT を反応性テンプレートと して作製することもできる。

一例として , 以下の反応スキームにて , 高温用あるい は高安定性圧電材料として知られる多成分系 Bi 層状構

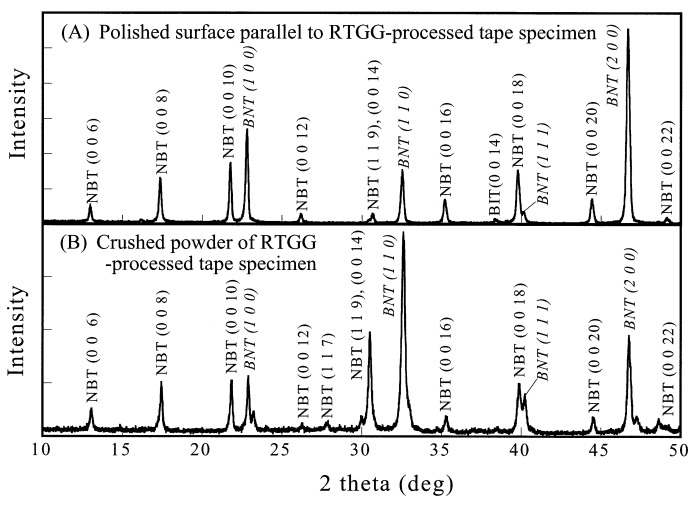

Fig. 13 X-ray diffraction patterns of RTGG-processed BNTNBT tape specimen for (A) the polished parallel surface and (B) the crushed powder.

造 (BLS; Bi layer-structured) 化合物の配向セラミックス を設計した ${ }^{11)}$ 。

$$
\begin{array}{r}
4 \mathrm{Bi}_{4} \mathrm{Ti}_{3} \mathrm{O}_{12}+22 \mathrm{Bi}_{2} \mathrm{O}_{3}+15 \mathrm{CaCO}_{3}+48 \mathrm{TiO}_{2} \\
\rightarrow 15 \mathrm{CaBi}_{4} \mathrm{Ti}_{4} \mathrm{O}_{15}(\mathrm{CBT})+15 \mathrm{CO}_{2} \uparrow
\end{array}
$$

BNKT と同樣なプロセスにより，単相で c 面が一軸配 向した多結晶 CBT セラミックスを得た。この焼結体の 配向面に垂直面と平行面の微組織(研磨後熱エッチング) を Fig. 14 に示す。板状粒子がテープ成形方向に配列し ている。ただし，BNKTの場合とは異なり，CBTの分 極軸は c 面内に存在するため, テープ成形面 (c 面配向 面；//面とする）とは垂直な面（上面とする）に電極を 設けて分極処理を行った。Fig. 15 に示したX線回折パ ターンに示したように，この上面では配向面と垂直な $\{200\}$ 面 (分極軸に垂直) および $\{220\}$ 面の回折ピー クが高い。

このため，無配向焼結体，上焼結体，//焼結体を分極 して圧電特性を比較すると，電界と分極のべクトル内積 が最も大きくなる上試料で最も高い值を示す。(単純) ペロブスカイト構造化合物よりも異方性が大きな層状ペ ロブスカイト構造では配向効果も大きく，Table 1 に示 すように，上試料は無配向試料の 3-4 倍の電気機械結合 係数 $\left(k_{33}\right)$, 圧電定数 $\left(\mathrm{d}_{33}, \mathrm{~g}_{33}\right)$ を発現する ${ }^{11}$ 。

\section{4.ま と め}

以上のように , 層状化合物のテンプレートと光の insitu 反応を利用して配向セラミックスを作製する RTGG 法を紹介した。この方法の長所は，

(1) 単純ペロブスカイトのように，異方性の小さな結 晶構造の物質の配向多結晶を作製できること，及び，

（2）複雑組成の配向多結晶を作製できることである。 


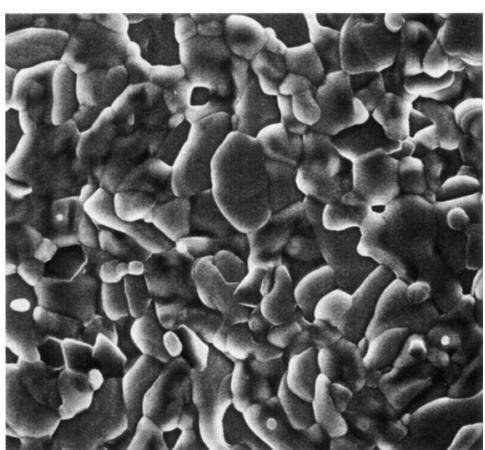

(A)

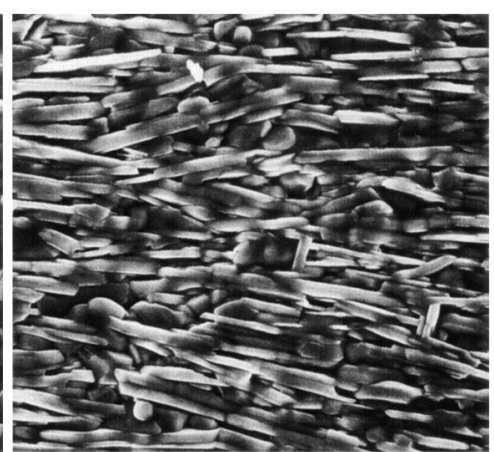

(B)

Fig. 14 SEM images of RTGG-processed $\mathrm{CaBi}_{4} \mathrm{Ti}_{4} \mathrm{O}_{15}$ (CBT) ceramics for the thermally-etched surfaces (A) parallel and (B) perpendicular to the tape surface.

Table 1 Piezoelectric and dielectric properties of textured and randomly-oriented $\mathrm{CaBi}_{4} \mathrm{Ti}_{4} \mathrm{O}_{15}(\mathrm{CBT})$ ceramics.

\begin{tabular}{lccc}
\hline & RTGG; $\perp$ to tape & RTGG; //to tape & Random orientation \\
\hline$\varepsilon_{33}{ }^{\mathrm{T}} / \varepsilon_{0}$ & 139 & 153 & 149 \\
$\tan \delta(\%)$ & 0.09 & 0.04 & 0.13 \\
$k_{\mathrm{p}}(\%)$ & 4.8 & 1.4 & 4.7 \\
$k_{31}(\%)$ & 3.2 & 0.9 & 2.9 \\
$k_{\mathrm{t}}(\%)$ & 53.4 & 16.2 & 16.2 \\
$k_{33}(\%)$ & 53.5 & 16.2 & 16.9 \\
$\mathrm{~d}_{31}\left(\times 10^{-12} \mathrm{C} / \mathrm{N}\right)$ & 2.8 & 0.9 & 2.8 \\
$\mathrm{~d}_{33}\left(\times 10^{-12} \mathrm{C} / \mathrm{N}\right)$ & 45 & 17 & 15 \\
$\mathrm{~g}_{31}\left(\times 10^{-3} \mathrm{Vm} / \mathrm{N}\right)$ & 2.3 & 0.6 & 2.1 \\
$\mathrm{~g}_{33}\left(\times 10^{-3} \mathrm{Vm} / \mathrm{N}\right)$ & 36.5 & 12.5 & 11.4 \\
\hline
\end{tabular}

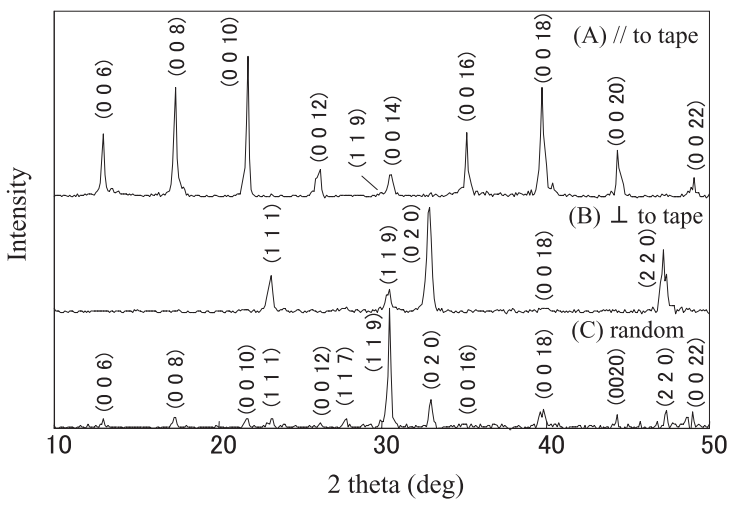

Fig. 15 X-ray diffraction patterns of (A) parallel and (B) perpendicular surfaces of the RTGG-processed CBT specimen as well as (C) conventionally-processed (randomly-oriented) CBT specimen.

セラミックスの粉体プロセスで単結晶並みの高特性が 実現できないか, という期待が開発のきっかけになった
が，(2) の特徵を活かせば, 融液から合成する単結晶で は実現できないような組成, あるいは均一な組成が得ら れにくい系でも，焼結法で配向多結晶として実現できる 可能性がある。

この結果得られた $\{100\}$ 配向単純ペロブスカイト型 セラミックスは煉瓦塀，\{001\} 配向ビスマス層状セラミ ックスはスレート積みに似た，独特の微組織を呈した。 これら 2 種類の配向組織は, テンプレートと生成物の結 晶構造における表面エネルギーの異方性を反映したもの である。

完璧に方位の揃つた単結晶を作製し，物質の本質的特 性を引き出すのも材料技術の1つの極かもしれない。光 の一方，本 RTGG 法のように，「いい加減なやり方で， そこここ揃った材料を作り，本質に近い特性を発現させ る」という所にも（いや，という所にこ光），材料技術 のフロンティアがあるのではないだろうか , などと思う のである。

また，今回示した圧電材料だけでなく，磁性体，イ才 
ン伝導体，熱電体など，物性の異方性を強調する配向多 結晶を実現することにより材料特性が向上する一連の物 質に対するプロセス手段としての発展が期待される。

\section{謝辞}

共同研究者として慶應義塾大学理工学部の木村敏夫先 生, 豊田中央研究所の竹内嗣人, 齊藤康善, 妹尾与志木 の3 氏に厚く御礼申し上げます。

\section{文献}

1)「100万人の金属学＼cjkstart基礎編」幸田成康編 (アグネ技 術センター，1966).

2) T. Tani and D.A. Payne: Brit. Ceram. Proc. 52, 88 (1994).
3) T. Tani, J.-F. Li, D.D. Viehland and D.A. Payne: J. Appl. Phys. 75, 3017 (1994).

4) H. Watanabe, T. Kimura and T. Yamaguchi: J. Am. Ceram. Soc. 74, 139 (1991).

5) T. Takenaka and K. Sakata: Jpn. J. Appl. Phys. 19, 31 (1980).

6) 広田栄一，釘宮公一，西尾武之：粉体および粉末冶 金 26, 123 (1979).

7) T. Tani and J. Korean: Phys. Soc. 32, S 1217 (1998).

8) T. Tani, T. Takeuchi and Y. Seno: Ceram. Trans, 104, Perovskite Oxides for Electronic, Energy Conversion, and Energy Efficiency Applications, 267 (2000).

9) S.-E. Park and T.R. Shrout: J. Appl. Phys. 82, 1804 (1997).

10) Y. Seno and T. Tani: Ferroelectrics 224, 365 (1999).

11) T. Takeuchi, T. Tani and Y. Saito: Jpn. J. Appl. Phys. 38, 5553 (1999). 